\title{
Żydowscy żołnierze Symona Petlury i Jewhena Petruszewycza. Rzecz o ciekawym opracowaniu Jarosława Tynczenki
}

\author{
Jarosław Tynczenko, Pid zirkoju Dawyda. \\ Jewrejśki nacjonalni formuwannja w Ukrajini \\ w 1917-1920 rokach, Kyjiw 2014 („Militaria \\ Ucrainica") $)^{1}$
}

Historycy zajmujący się dziejami Ukraińskiej Republiki Ludowej (URL) atamana Symona Petlury, Zachodnioukraińskiej Republiki Ludowej (ZURL) prezydenta Jewhena Petruszewycza i Państwa Ukraińskiego hetmana Pawła Skoropadskiego (wszystkie wymienione twory państwowe istniały w latach 1917-1920) nie opracowali jeszcze wielu bardzo interesujących zagadnień dotyczących tej tematyki lub też opisywali je pobieżnie, często nie wnikając w szczegóły. Jednym z takich słabo poruszonych tematów jest kwestia służby wielu cudzoziemców w siłach zbrojnych wymienionych państw. Lukę dotyczącą Żydów w ukraińskich mundurach stara się wypełnić ukraiński historyk Jarosław Tynczenko w swej pracy pt. Pid zirkoju Dawyda. Jewrejśki nacjonalni formuwannja w Ukrajini w 1917-1920 rokach (Pod gwiazda Dawida. Żydowskie formacje narodowe na Ukrainie w latach 1917-1920), wydanej w 2014 r. w Kijowie w ramach dosyć popularnej serii „Militaria Ucrainica”.

Opracowanie składa się z przedmowy, aż 27 krótkich rozdziałów oraz dwóch aneksów. Autor przyjął układ chronologiczno-problemowy. W rozdziałach 2-14 opisał próby formowania żydowskiego ruchu wojskowego oraz oddziałów na terenie Imperium Rosyjskiego po rewolucji lutowej 1917 r. W kolejnych czterech (15-18) Tynczenko przedstawił dramatyczny los żydowskich formacji na południu Ukrainy w latach 1918-1919. Rozdział 19 poświęcił działalności żydowskich samoobron w innych regionach Ukrainy, w Rosji oraz na Białorusi. W rozdziałach 20-27 ukraiński badacz opisał

${ }^{1}$ Dla wygody czytelnika autor zamieszcza zapis oryginalny: Ярослав Тинченко, Під зіркою Давида. Єврейські національні формування в Украӥні в 1917-1920 роках, Київ 2014, ss. 168. 
sformowanie i szlak bojowy żydowskich oddziałów i żołnierzy w Armii Czynnej URL oraz szczególnie Armii Halickiej. W końcu w ostatnim rozdziale przedstawił ciekawy epizod wyprawy parowca „Rusłan” z portu w Odessie do Jaffy w Palestynie w listopadzie $1919 \mathrm{r}$.

Ograniczenia wydawnicze nie pozwalają na omówienie każdego z tych drobnych rozdziałów osobno, więc autor recenzji skupił się na najciekawszych. Z pewnością do takich należy rozdział piąty (s. 26-29), w którym Tynczenko opisał zagadnienie zjazdów i konferencji żydowskich żołnierzy $\mathrm{w}$ armii rosyjskiej. Wymienił nazwiska organizatorów tychże wydarzeń, a także daty poszczególnych spotkań wojskowych w różnych zgrupowaniach frontów Północnego, Zachodniego, Południowo-Zachodniego, Rumuńskiego, Kaukaskiego oraz Kazańskiego Okręgu Wojskowego. Zjazdy były momentami nie tylko debat na temat losu Żydów w trzeszczącym w szwach Imperium Rosyjskim, ale również zażartych sporów co do formowania żydowskich oddziałów i samoobron. Szczególnie mocno występował przeciwko tej idei lewicowy Bund, który starał się dowieść, iż tworzenie żydowskich formacji wojskowych tylko podsyci antysemityzm i zwiększy zagrożenie pogromami.

Kolejnymi bardzo interesującymi fragmentami opracowania są rozdziały poświęcone szlakowi bojowemu pierwszych żydowskich oddziałów i samoobron w coraz bardziej pogrążającym się w rewolucyjnym chaosie Imperium Rosyjskim. Są to przede wszystkim rozdziały dziewiąty (s. 35-38), dwunasty (s. 45-47), trzynasty (s. 48-52), piętnasty (s. 56-64) oraz szesnasty (s. 65-75). Osobną uwagę warto poświęcić rozdziałowi dziewiętnastemu (s. 85-89) pt. Żydowskie samoobrony w innych regionach Ukrainy, Rosji oraz Białorusi $w$ latach 1918-1920. Jest to temat niemal nieznany polskiemu czytelnikowi, któremu losy Żydów na Ukrainie, w wymienionych latach, kojarzą się głównie z pogromami. Tynczenko w przystępny i zwięzły sposób opisał w nich ciekawe przypadki formowania, działalności, składu osobowego i końca różnych żydowskich oddziałów samoobrony. Wiele z nich było tworzonych $\mathrm{z}$ młodych przedstawicieli skrajnie lewicowych ugrupowań politycznych, w tym bolszewików. Należeli oni zarówno do Gwardii Czerwonych jak i do żydowskich samoobron, które w zamian za udzieloną zgodę na swe powstanie miały zachować neutralność. Prowadziło to do sytuacji, gdy np. w trakcie wojny ukraińsko-bolszewickiej na początku 1918 r. młodzi komuniści pochodzenia żydowskiego strzelali do Ukraińców z budynków należących do żydowskiej społeczności, a wśród kozaków URL rosło błędne przekonanie, iż Żydzi masowo popierają rosyjskich bolszewików (s. 85-86). Inny charakter miały jednak żydowskie oddziały na południu Ukrainy - tam dominowały silnie syjonistyczne nastroje, a samoobrony często okazywały się groźnym przeciwnikiem dla oddziałów atamanów, zajmujących się w dużej mierze łupiestwem, jak i oddziałów Sił Zbrojnych Południa Rosji, 
również niestroniących od organizowania antysemickich pogromów. Przykładem były oddziały samoobrony w Hołcie i Olhopolu (s. 87-88). W tym też rozdziale ukraiński badacz opisuje problem zbrodni, jakich wiele miało miejsce na terenie byłego Imperium Rosyjskiego. Warto przyjrzeć się przy tym jego interpretacji masakry, do jakiej doszło w Proskurowie 14 lutego 1919 r. ${ }^{2}$ (s. 86) - przypomina on, iż przed pogromem doszło tam do próby bolszewickiego przewrotu, w którym brali udział również Ukraińcy. Po jego stłumieniu kozacy atamana Iwana Semensenki zgładzili również i rodaków-zdrajców, których później błędnie (a być może i celowo) zaliczono w poczet „żydowskich” ofiar pogromu. Niemniej Tynczenko nie zaprzecza temu, iż do zbrodni na ludności żydowskiej doszło.

W końcu należy przejść do kolejnej części, bardzo ciekawej również dla polskiego czytelnika, czyli zagadnienia udziału Żydów w wojnie o niepodległość URL i ZURL w latach 1918-1920. Na uwagę zasługuje fragment poświęcony służbie wojskowej Żydów w Armii Czynnej URL w latach 1918-1920 (rozdz. 20-21, s. 90-92) w dużej mierze z uwagi na polemizowanie $\mathrm{z}$ dosyć popularnym stereotypem totalnie antysemickiego charakteru sił petlurowskich. Tynczenko przedstawia czytelnikowi losy wymienionych $\mathrm{z}$ imienia i nazwiska żydowskich weteranów (np. sotnyk $a^{3}$ Semena Akersona czy szeregowego Abrahama Szkarbula, który po zamachu na Petlurę pojechał do Paryża, by zaświadczyć o fałszywości zarzutów dotyczących rzekomego antysemityzmu lidera URL). Ponadto w recenzowanym opracowaniu znajduje się obszerny fragment poświęcony formowaniu i działalności milicji żydowskiej w Galicji Wschodniej, a szczególnie we Lwowie w listopadzie $1918 \mathrm{r}$. (rozdz. 23, s. 97-106). Nie mniej ciekawe są rozdziały, w których Tynczenko opisał szlak bojowy żydowskich formacji Armii Halickiej, biorących udział w walkach przeciwko WP: Żydowskiego Kurenia ${ }^{4}$ Szturmowego (rozdz. 26, s. 117-129) i Konnej Sotni ${ }^{5}$ Broni Maszynowej czetara $^{6}$ Salka Rottenberga (rozdz. 25, s. 108-116).

Treść opracowania została oparta głównie na rosyjskich i ukraińskich materiałach archiwalnych, prasie, relacjach oraz monografiach. Tynczenko

\footnotetext{
${ }^{2}$ Więcej informacji na temat największego i zarazem najkrwawszego pogromu dokonanego przez formacje Armii URL zob. m.in. O. В. Будницкий, Российские евреи между красными и бельми (1917-1920), Москва 2005, s. 217-218; H. Abramson, Mołytwa za władu. Ukrajinci ta jewreji pid czas rewolucji (1917-1920), Kyjiw 2017, s. 193-202.

${ }^{3}$ Sotnyk - ukraiński odpowiednik kapitana.

${ }^{4}$ Kureń - ukraiński odpowiednik batalionu.

${ }^{5}$ Sotnia - ukraiński odpowiednik kompanii.

${ }^{6}$ Czetar - ukraiński (halicki) odpowiednik stopnia porucznika. W URL występował jako czotar.
} 
wykorzystał dokumenty z Rosyjskiego Państwowego Archiwum Wojskowo-Historycznego (zespół 725) oraz Centralnego Archiwum Wyższych Organów Władzy i Administracji Ukrainy w Kijowie (zespoły: 263, 1076, 1688, 2188 i 3287). Część informacji zaczerpnął z gazety „Odesskyj Łystok” wydawanej w Odessie w latach 1918-1919. W bibliografii znajduje się również szereg rosyjsko- i ukraińskojęzycznych relacji oraz przede wszystkim opracowań dotyczących tak działań wojennych, formowania oddziałów wojskowych, jak i życia Żydów na Ukrainie w dobie rosyjskiej wojny domowej 1917-1920 oraz walk o niepodległość ZURL i URL w latach 1918-1921.

Autor książki umieścił w niej 57 zdjęć. Przedstawiają one sytuacje z życia codziennego, uroczystości, architekturę czy w końcu Żydów w mundurach formacji austro-węgierskich, rosyjskich i ukraińskich. Dwa z nich to zeskanowane dokumenty Armii Czynnej URL. Zwracają uwagę również cztery szczegółowe i kolorowe szkice autorstwa Bohdana Pirczaha. Przedstawiają kolejno: szeregowego żydowskiego I Odeskiego Batalionu w 1918 r., oficera żydowskiej milicji miasta Lwów w listopadzie 1918 r., oficera Żydowskiego Kurenia Szturmowego Armii Halickiej w czerwcu-lipcu 1919 r. oraz chorążego Armii Czynnej URL Akersona latem 1920 r.

$\mathrm{Z}$ uwag negatywnych należy wymienić bardzo skromną liczbę polskich relacji dotyczących wojny polsko-ukraińskiej 1918-1919 oraz, będącego epizodem w walkach o Lwów w listopadzie 1918 r., pogromu ludności żydowskiej. W bibliografii znajdują się jedynie wspomnienia Czesława Mączyńskiego ${ }^{7}$, ale bynajmniej nie chodzi tu o jego słynną książkę Oswobodzenie Lwowa ${ }^{8}$, oraz Ozjasza Wassera, opublikowane w wydawnictwie Obrona Lwowa. 1-22 listopada $1918^{9}$. Niekorzystnie wygląda również opisanie służby wojskowej Żydów w Cesarsko-Królewskiej Armii Austro-Węgierskiej na podstawie zaledwie jednej austriackiej monografii ${ }^{10}$. W bibliografii brakuje ponadto rosyjskiego opracowania Jewriei w russkoj armii 1827-1914 ${ }^{11}$. Dziwi również niewykorzystanie przez Tynczenkę popularno-naukowego opracowania Ołeha Stecyszyna Łandsknechty Hałyćkoji Armiji ${ }^{12}$ z 2012 r., w którym znajduje się szereg ciekawych informacji o Żydach służących w Armii Halickiej. Jakkolwiek

${ }^{7}$ Cz. Mączyński, O stanowisku Żydów w czasie walk listopadowych [w:] Obrona Lwowa. 1-22 listopada 1918, t. II: Źródła do dziejów walk o Lwów i województwa południowo-wschodnie 1918-1920, red. E. Wawrzkowicz, Lwów 1936, s. 1036-1047.

${ }^{8}$ Idem, Oswobodzenie Lwowa (1-24 listopada 1918 roku), t. I, Warszawa 1921.

${ }^{9}$ O. Wasser, Rola Żydów w listopadowej obronie Lwowa [w:] Obrona Lwowa..., t. II, s. $1052-1063$.

${ }^{10}$ A. Erwin, A. Schmidl, Juden in der k.(u)k. Armee 1788-1918, Eisenstadt 1989.

${ }^{11}$ Й. Петровский-Штерн, Евреи в русской армии 1827-1914, Москва 2003.

${ }^{12}$ O. Stecyszyn, Landsknechty Hałyćkoji Armiji, Lwiw 2012. 
nie jest to praca pozbawiona błędów, to autor Pid zirkoju Dawyda powinien przynajmniej zasygnalizować fakt istnienia takiej pozycji. W bibliografii brakuje również szeregu innych ważnych monografii dotyczących walk o niepodległość URL i ZURL, choćby Mychajła Kowalczuka ${ }^{13}$, Lwa Szankowskiego $^{14}$, Macieja Krotofila ${ }^{15}$ czy Michała Klimeckiego ${ }^{16}$. Kolejną wadą recenzowanego opracowania jest niewykorzystanie przez Tynczenkę zasobów lwowskiego Państwowego Archiwum Obwodu Lwowskiego (zespół 257) oraz Centralnego Archiwum Wojskowego Wojskowego Biura Historycznego w Warszawie (głównie zespół 380). W obu instytucjach ukraiński badacz znalazłby wiele cennych dokumentów dotyczących wojny polsko-ukraińskiej 1918-1920, udziału Żydów w owym konflikcie oraz pogromu we Lwowie.

W opracowaniu znalazło się kilka błędów merytorycznych. Do najważniejszych należy zaliczyć stwierdzenie, jakoby Akerson zginął w getcie w czeskiej Pradze podczas niemieckiej okupacji (s. 92). Na Ukrainie rzeczywiście dosyć rozpowszechniona jest wersja o jego śmierci z rąk Niemców w 1944 r. - w jego rodzimej Winnicy ufundowano na jego cześć tablicę pamiątkową, na której wykuto taką właśnie informację. W rzeczywistości ten żydowski weteran ukraińskich sił zbrojnych przeżył II wojnę światową, o czym przypomniał niedawno na łamach portalu „Ukraińska Prawda” izraelski historyk i dziennikarz Szymon Bridman ${ }^{17}$. Drobnym błędem jest też nazwanie Salka Rottenberga czotarem, a nie czetarem. Nie jest to literówka, ale błąd wynikający z różnic w nazewnictwie tego stopnia wojskowego w Armii Halickiej (gdzie występowali czetarzy oraz czety $^{18}$ ) i Armii Czynnej URL (tam z kolei służyli czotarzy na ogół dowodzący czotami). Bardziej można

\footnotetext{
${ }^{13}$ M. Kowalczuk, Newidoma wijna 1919 roku. Ukrajinśko-biłohwardyjśke zbrojne protystojannia, Kyjiw 2006; idem, Na czoli Siczowych strilciw. Wijśkowo-polityczna dijalnist' Jewhena Konowalcia w 1917-1921 rr., Kyjiw 2010; idem, Bez peremożciw. Powstanśkyj ruch w Ukrajini protybiłohwardyjśkich wijśk henerała A. Denikina (czerweń 1919 r. - lutyj 1920 r.), Kyjiw 2012.

${ }^{14}$ Ł. Szankowśkyj, Ukrajinśka Armija w Borot'bi za derżawnist', Miunchen 1958; idem, Ukrajinśka Hałyćka Armija: Wojenno-istoryczna studia, Winnipeg 1974.

${ }^{15}$ M. Krotofil, Ukraińska Armia Halicka 1918-1920. Organizacja, uzbrojenie, wyposażenie i wartość bojowa sił zbrojnych Zachodnio-Ukraińskiej Republiki Ludowej, Toruń 2002; idem, Kawaleria Ukraińskiej Armii Halickiej 1918-1920 [w:] Kawaleria przeciwników i sojuszników wojska polskiego w latach 1918-1921, red. A. Smoliński, Torun 2003; idem, Siły Zbrojne Ukraińskiej Republiki Ludowej (listopad 1918 r. - grudzień 1919 r.), Kijów 2011.

${ }^{16}$ M. Klimecki, Lwów 1918-1919, Warszawa 1998; idem, Polsko-ukraińska wojna o Lwów i Galicje Wschodniq 1918-1919, Warszawa 2000.

${ }^{17}$ Sz. Bridman, Zahadkowa dola jewrejśkoho heroja Ukrajiny, http://www.istpravda.com. ua/columns/2018/03/30/152230/ (dostęp: 20 V 2018 r.).

${ }^{18}$ Czeta - ukraiński (halicki) odpowiednik plutonu. W URL występował jako czota.
} 
Pid zirkoju Dawyda zarzucić zbytnią ogólnikowość - wiele z poruszonych przez Tynczenkę zagadnień należałoby rozwinąć.

Pomimo pewnych braków opracowanie Tynczenki jest bardzo wartościową pracą. Pid zirkoju Dawyda wypełnia sporą lukę dotyczącą służby Żydów w siłach zbrojnych obu ukraińskich republik z lat 1917-1920. Ponadto porusza fragment bardzo kontrowersyjnych relacji ukraińsko-żydowskich.

Marek Bogdan Kozubel (Biuro Edukacji Narodowej Instytutu Pamięci Narodowej) orcid.org/0000-0002-8096-0014 